\title{
Municipal Solid Waste Suitable Disposal Site Selection, Case Study, Wolkite Town, Ethiopia
}

\author{
Yenenesh Hailu*, Terefe Hanchiso and Abreham Bereta \\ Department of Natural Resources Management, Wolkite University, Ethiopia
}

Submission: July 15, 2019; Published: July 30, 2019

*Corresponding author: Yenenesh Hailu, Department of Natural Resources Management, Wolkite University, Ethiopia

\begin{abstract}
Solid waste disposal area is a matter of public health concern. selection of an appropriate site would minimize environmental impact and forms a sound basis solid waste management, this study conducted with the aim of locating suitable land fill site for the case wolkite town, thus in order to Locating new solid waste landfill area multiple aspects, such as land use/land cover, soil and slope were used as factors. Moreover, proximity from surface water such as: rivers/streams, groundwater supply well point, road, public facility such as: schools, health centers, administrative offices, churches, mosques, other built up areas, and cultural sites were considered as landfill sitting constrains, data analysis were conducted through GIS software finally candidate land fill site were identified ,thus the municipality recommended to use the indicated land fill site rather than the former unsuitable land fill.
\end{abstract}

Keywords: Solid waste; Disposal; Land fill; GIS

\section{Introduction}

A landfill is a method of solid waste disposal that functions without creating hazard to public health or safety. Land filling is necessary for municipal solid waste disposal, but every landfill has its own finite capacity. The most common approach to extending the life of landfills is to introduce recycling, composting, and incineration into the solid waste disposal system [1].

In most cities and towns of developing world, inappropriate handling and disposal of municipal solid waste is the most visible cause of environmental degradation, i.e., air pollution, soil contamination, surface and ground water pollution, etc., resulted from improper disposal of municipal solid wastes [2].

Shortage of land for waste disposal and inappropriate landfill site is one of the biggest problems in most of large urban areas in the world which has its negative impact on human, and environment [3].

A waste disposal area is a matter of public health concern. Considering the high rate of urbanization, one should take the long-term land use planning of suburbs into consideration to locate the disposal area. Moreover, the present and future of garbage trucks traffic should be considered. There are many factors which should be considered in locating a waste disposal area. Obviously, the type of ground selected for this purpose directly affects the design, usage and the tools needed for the effective operation [1].
These factors mainly consist of: public health, extend and topography of the area, hydrology, geology drainage system and weather of the area, the availability of landfills in the area to cover the wastes, proximity to the residential and industrial areas, the distance to and from the city, the weather of the area, the drainage system of the area, cost and the future land use of the area [1].

Selection of an appropriate site would minimize environmental impact and forms a sound basis for its further management [4]. However, this is a tedious, costly and difficult task requiring simultaneous contemplation of several criteria. Identification of the suitability of potential landfill sites, and modifications to existing facilities, requires a comprehensive assessment of site conditions and potential impacts on the environment. This includes consideration of topography, surface water, drainage, hydrogeology (groundwater), geology; climate (including air quality and odor modeling) and flora and fauna, access and distance from the community the landfill will service.

The amount of waste that ever reaches dumps sites or landfills in Ethiopia is small fraction. a number of studies have shown that only $43 \%$ of waste is collected in the country are properly collected and disposed in open landfills. The remaining waste is indiscriminately disposed in drainage lines, open spaces, street sides or is informally burned.

Wolkite is one of the swiftly urbanizing centers but has been tackled with an increasingly growing urban waste generation 
and management problem. There are many wastes that dispose from different source and the way of management of those solid waste is poor, the town has one major land fill site which is $12 \mathrm{~km}$ far from the town, the land fill site found at Gasore kebele.

In addition, the solid waste disposal practice using solid waste container is not good, moreover there is disposal of waste in drainage lines, open spaces, street sides or is informally burned are common the many are area of wolkit town. Thus, objective of this study to identify environmentally socially and economically friendly candidate land fill site in wolkite town.

\section{Methodologies}

\section{Spatial data collection}

In this study, the environmental, social and economic factors or constraints to be considered for sitting landfill site were considered and respective data was obtained from different primary and secondary sources.

Water points, river, roads, administrative offices, water facilities, public service centers, land use/land cover, Digital Elevation Model (DEM), soil and administrative boundary datasets of the municipality is obtained from Ethiopian Mapping Agency and overlaid with other data of the municipality. The DEM was used to derive slope and drainage pattern of the municipality. Master plan of the municipality is obtained in hardcopy and digitized and geo-referenced in Arc GIS environment.

Data preprocessing for coordinate and projection conversion was performed with QGIS and ArcGIS software. Moreover, Observation is made to identify the current open landfill site of the municipality. Data such as location, altitude, ground control points and distance from main features as well as picture was captured from open landfill site.

\section{Spatial data analysis}

Solid waste landfill site selection is the complex and expensive process that requires many conflicting criteria. In this research land use/land cover, soil and slope were used as factors. Moreover, proximity from surface water such as: rivers/ streams, groundwater supply well point, road, public facility such as: schools, health centers, administrative offices, churches, mosques, other built up areas, and cultural sites were considered as landfill sitting constrains.

All the factors and constrains were internally classified in to five classes (very high, high, moderate, low and very low) with values ranging from 1 to 5 , where value of 5 denotes the most suitable and value 1 denotes the least suitable for all factors and constrains considered. Weights for each class of criteria were derived in IDRISI and ILWIS software environment using AHP methods. The method uses the expert preferences for comparing the classes and prepare matrix table. Accordingly, weight was derived for each class giving total sum of 1 (Table 1). As all factors considered (except proximity from surface water and land use/land cover) were reclassified in to five classes of very high, high, moderate, low and very low with values ranging from 5 to 1 respectively. The weight derived here was used for all factors considered.

Table 1: AHP weight derivation of criteria classes. Criteria weights calculated from AHP weight derivation as suitability indexes.

\begin{tabular}{|c|c|c|}
\hline Suitability Class & Rating (Preference) & Weight \\
\hline Very Low Suitability & 1 & 0.0618 \\
\hline Low Suitability & 2 & 0.0973 \\
\hline Moderate Suitability & 3 & 0.1599 \\
\hline High Suitability & 4 & 0.2625 \\
\hline Very High Suitability & 5 & 0.4185 \\
\hline \multicolumn{2}{|c|}{ Total } & 1 \\
\hline
\end{tabular}

Models used for data processing, management and analysis were built to convert, integrate, analyze and visualize data in ArcGIS model builder environment (Figure 1).

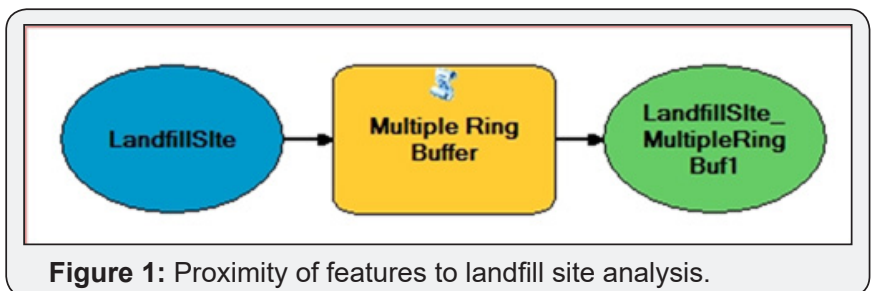

Result and Discussion

\section{Proposing new suitable site for landfill}

Locating new landfill area requires multiple aspects, data, analysis and issues. These factors mainly consist of: public health issues, environmental aspects, topography of the area, hydrology, geology, drainage system and weather of the area, the availability of landfills in the area to cover the wastes, proximity to the residential and industrial areas, the distance to and from the city, drainage system, cost and current/future land use of the area [1].

It also requires a comprehensive assessment of site conditions and potential impacts on the environment. This includes consideration of topography, surface water, drainage, hydrogeology (groundwater), geology, air quality and odor modeling and flora and fauna, access and distance from the community.

\section{Slope}

Slope is one of the determining topographic factors in landfill site selection. Generally, foot slope and gentle slope is suitable for locating landfill site while gentle slope is more suitable than other slope classes for landfill site selection. In this research, slope with $0-2 \%$ is considered as low, $2-8 \%$ is very high, $8-15 \%$ is high, $15-30 \%$ moderate and $>30 \%$ very low suitability.

The middle part of municipality is not suitable for landfill site selection because sloping to strongly sloping topography is more saturated in this region than other parts. Whereas: the northern and southern tips of municipality have suitable area for landfill site selection in terms of slope criteria. 
Landfill area should not be located on a hill with an unstable slope and land slide areas. Areas located on the gently sloping are preferred than level ground and highly sloping areas as stated in [5] because of highly sloping areas could cause a fatal avalanche especially when there is rain or high-water seepage. Moreover, steep slopes can pose difficulty in construction or leveling work, which can be additional cost; it can also reduce the stability of the side slopes and increase risk of landslides.

Moreover, flat topography is not recommended for landfill due to water logging problem. Suitable slope for landfill site is gentle slope that enables easier storm water and leachate control operations and movement of vehicles to and from the site (Figure 2).

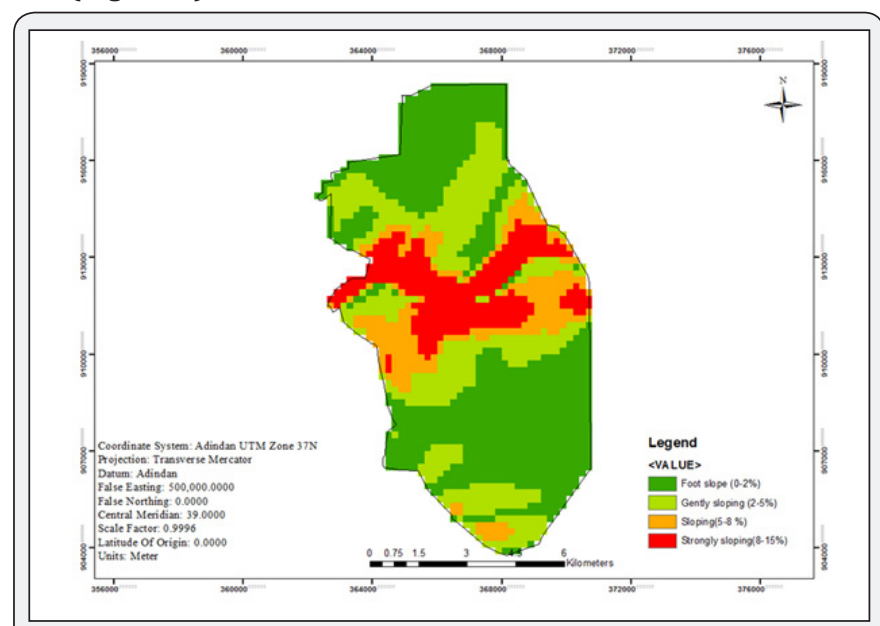

Figure 2: Slope in percent of the study area.

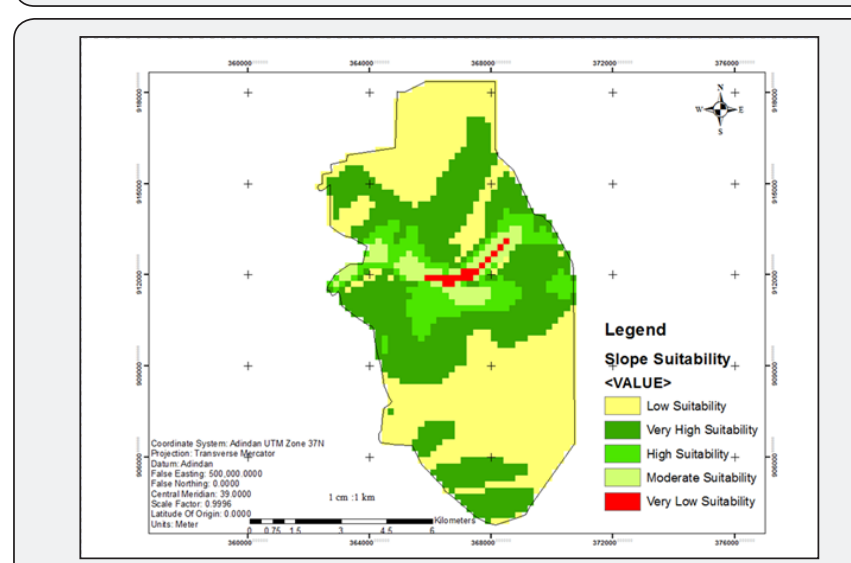

Figure 3: Slope in suitability.

Various literatures used different slope values for landfill site selection [6] set areas with slope $<15-20 \%$ as the best site for landfill, while [1] describe slope $<12 \%$ as the best site and slope $>12 \%$ unsuitable for landfill. Moreover, [7]) state that areas with slope $<20 \%$ is optimum site for landfills. In this research, slope with $0-2 \%$ is considered as low, $2-8 \%$ is very high, $8-15 \%$ is high, $15-30 \%$ moderate and $>30 \%$ very low suitability (Figure 3 ).

\section{Distance from settlement}

Landfill site is not recommended in proximity to settlement areas. The built-up areas that include commercial areas, governmental and private institutions, schools, health centers, religious institutions, educational institutions, residences and other social services are considered as settlement areas in this study. Landfill site is usually recommended to be one kilometer far from settlement areas. [1,6-10], set distance from settlements to be $3000 \mathrm{~m}, 500-2000 \mathrm{~m}, 3000 \mathrm{~m}$ multi-ring buffers.

Wolkite town is covered by built up area. Due to fast expansion of urban settlement, built up area is expanding every time.

Landfills should not be placed too close to high-density urban areas in order to mitigate conflicts relating to the Not in My BackYard syndrome (NIMBY). This guard against health problems, noise complaints, odour complaints, decreased property values and mischief due to scavenging animals [11]. He has stated landfills should be prohibited within 3000 meters from village settlements. In this study, multi ring buffer of $300 \mathrm{~m}, 300-500 \mathrm{~m}$, $500-1000 \mathrm{~m}, 1000-1500 \mathrm{~m}$ and $>1500 \mathrm{~m}$ buffer distance was created to classify areas.

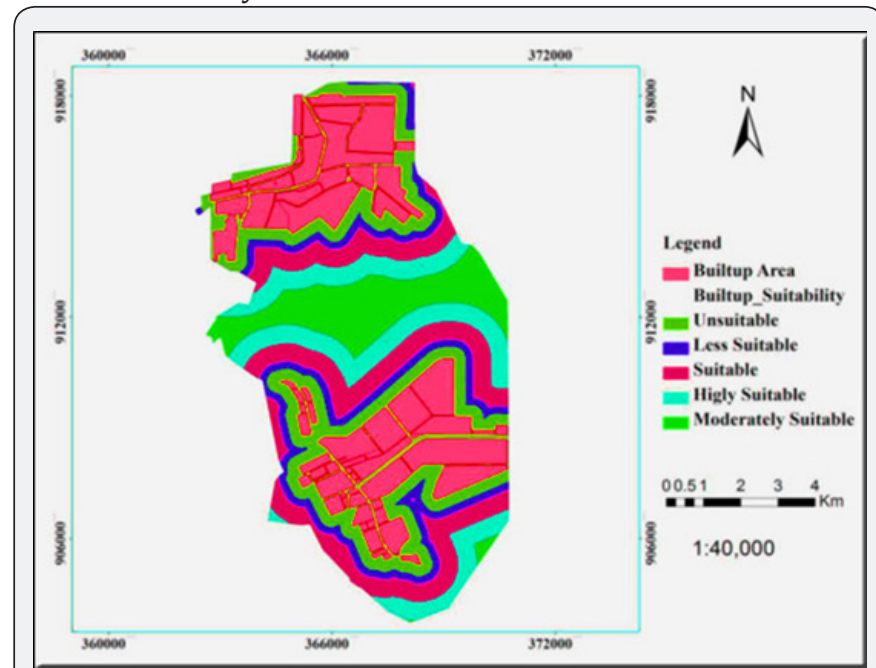

Figure 4: Suitability classes based on proximity to settlements.

Landfill site should not be placed near to settlement areas. If waste landfill site is located near to settlements different health problems, bad smell or odor, noise, decreased property values and scavenging animal complaints may arise. Air pollution is one of the big threats to public health if the landfill is located near to human settlements. In this study, multi ring buffer of $300 \mathrm{~m}, 300$ $500 \mathrm{~m}, 500-1000 \mathrm{~m}, 1000-1500 \mathrm{~m}$ and $>1500 \mathrm{~m}$ buffer distance was created to classify areas according to their suitability to locating new solid waste landfill site. Accordingly, areas nearer than $1000 \mathrm{~m}$ are considered as unsuitable while areas far away by more than $1000 \mathrm{~m}$ distance area considered as suitable (Figure 4).

\section{Land use}

The current and future use of land is one of important criteria used while selecting landfill site. Usually, land with less socio-economic, environmental and political value or cost is recommended as disposal site. As it is a matter of public health concern, considering the high rate of urbanization, one should 
take the long-term land use planning of land into consideration to locate the disposal area. Moreover, the present and future of garbage trucks traffic should be considered [1].

Fast urbanization is evidenced from different corners of the municipality, even though the built-up area is saturated on the northern and southern corners of the municipality on the current scenario, due to expansion of public institutions and industry areas, the municipality has high potential for development. But, the future development plan of the town is not developed in usable way in the current research, therefore, the future land use is considered as the current. Obviously, the built-up area sprout is very fast and larger than the one displayed over here due to the very recent land use/ land cover dynamics.

The land use/ land cover was identified to be bare land, cereals farm, closed shrub land, enset and associated plantation, eucalyptus plantation, gallery forest, grass land, open shrub land, and settlement areas. The land uses identified as suitable for landfill site selection in this study are generally assumed to be of low value lands and less economically important than the site. Based on literatures $[6,12]$ and local, national and international standards, bare land is considered most suitable for landfill site than other land uses in this study. Grass land, open shrub land and closed shrub land are rated as moderately suitable, suitable and less suitable.

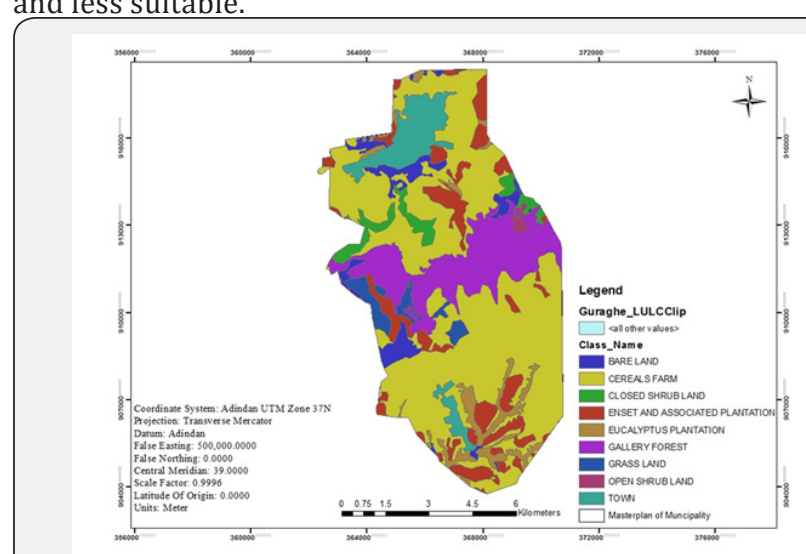

Figure 5: Land uses of municipality.

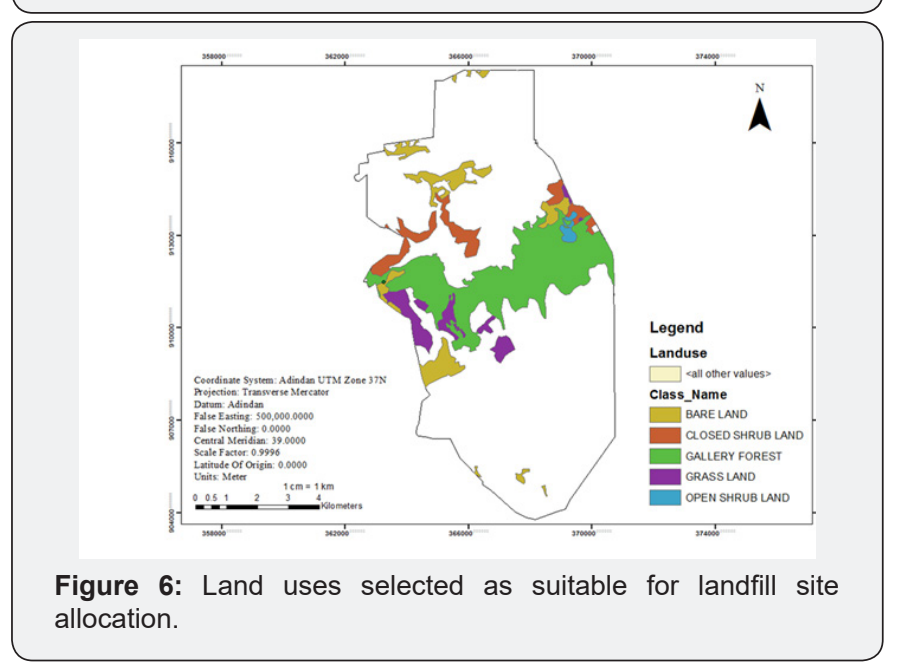

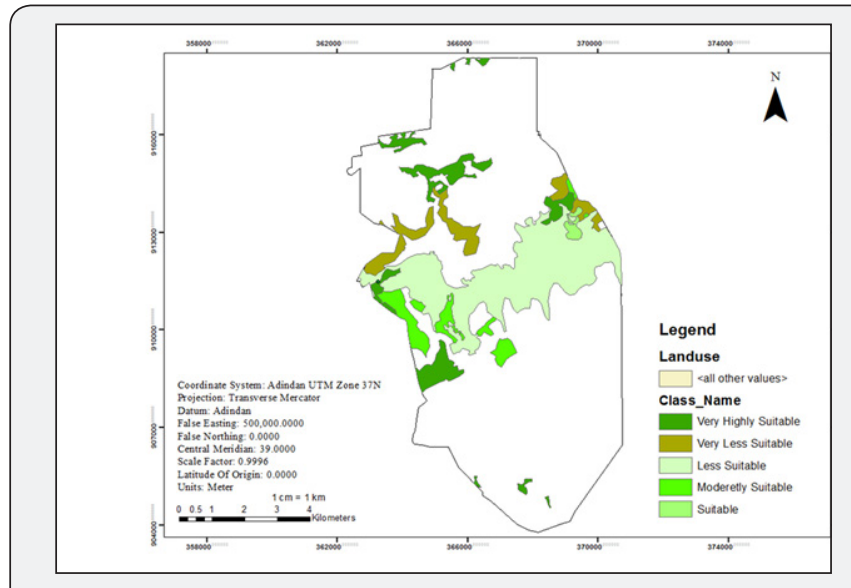

Figure 7: Suitability classes for landfill site allocation based on land use.

However, overall the municipality has very limited land size with bare land, grassland, closed shrub land and open shrub land which are considered as suitable for waste disposal site selection. Hence, additional land uses such as Overall, suitable land for landfill site that is fragmented and with small area size is found in municipality as can be seen in Figure 5, 6 \& 7.

\section{Distance from main road}

Roads are important features while locating landfill site. It should not be located very near to main road where the general public move due to public health problem as landfill can have harmful effect to health. Moreover, placing landfill site very far from road network is also not advised because it can hamper transportation and access to the site [1]. set $75 \mathrm{~m}$ buffer while [6] uses $50-100 \mathrm{~m}$ buffer from road as a minimum distance within which landfill should not be located. However, $100 \mathrm{~m}$ buffer distance is mentioned as the safest distance in $[4,7,8,13,14]$. This study used buffer distances of $100 \mathrm{~m}, 100-500 \mathrm{~m}, 500-1000 \mathrm{~m}$, $1000-1500 \mathrm{~m}$ and $>1500 \mathrm{~m}$ radiuses to classify into suitability classes (Figure 8).

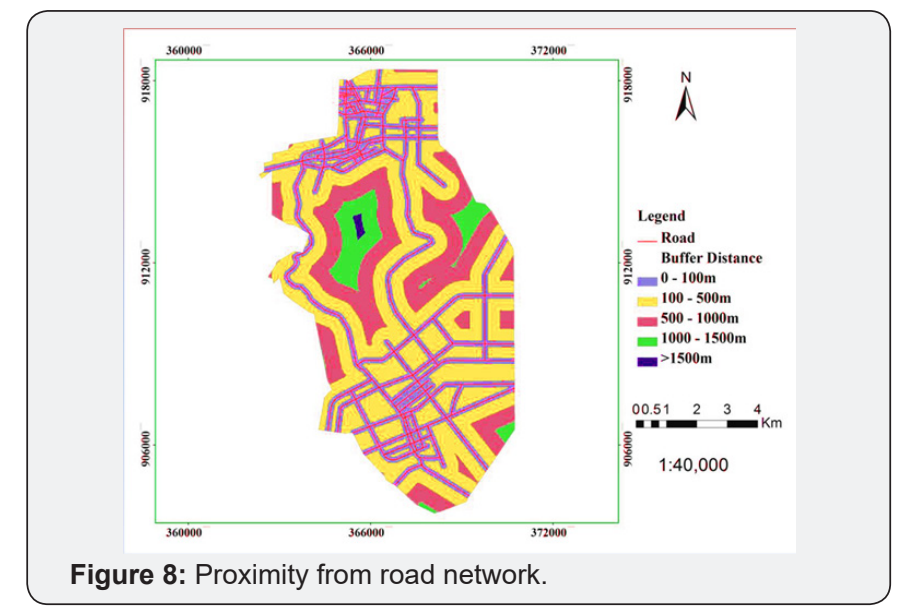

\section{Proximity to surface water}

According to [2] in towns of developing world, improper disposal of municipal waste is the most common cause of 
environmental degradation, i.e., air pollution, soil contamination, surface and ground water pollution. Open dumps pollute surface and ground water, soil and the natural environment.

Proximity of a landfill to streams/ rivers, groundwater well water points is an important environmental criterion in the landfill site selection so that water points may be protected from the runoff and leaching of the landfill. Hence, waste disposal should be placed away from water points. Otherwise, it can have irretrievable human and environmental effects (Figure 9).

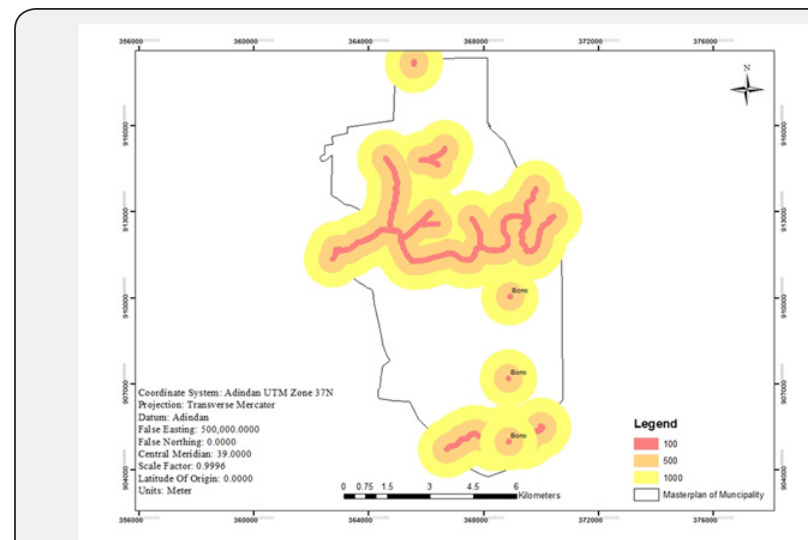

Figure 9: Proximity from water points.

Different literatures and standards were used to reclassify the rating of classes for each criterion/ constraint considered for selection of landfill site.

Multi-ring buffer zone of $50 \mathrm{~m}, 500-1000 \mathrm{~m}, 700 \mathrm{~m}$ was used for water points in $[1,6,11]$ to classify unsuitable site from suitable. [5] it is stated that a landfill must not be located within $100 \mathrm{~m}$ of any surface streams, lakes, rivers or wetlands according to riparian reserve guidelines produced by the Drainage and Irrigation Department, Sabah, Iran.

In this study, multi ring buffer zones of $100 \mathrm{~m}, 500-1000 \mathrm{~m}$ and $>1000 \mathrm{~m}$ buffers were set to identify suitable site with respect to water point constraint. Areas within $100 \mathrm{~m}$ radius of the water points were considered as very less suitable or unsuitable while areas away from $1000 \mathrm{~m}$ radius are very highly suitable for landfill site selection.

\section{AHP weight derivation}

Multi-criteria Evaluation (MCE) methodology is used for assigning criteria weights for each factor maps. When it comes to site selection problems or suitability models, the spatial MultiCriteria Analysis (Weighted Overlay) is the most commonly used method. Different weights were given in preference of each factor relative to other factor. Literatures propose several criterion-weighting procedures based on the judgments of decision makers in the multi-criteria decision [15-18].

Accordingly, one of the most promising is pair-wise comparison developed in context of a decision-making process is known as the AHP [6]. The IDRISI weight module utilizes the pair-wise comparison technique to help develop a set of factor weights that will sum to 1.0. More weight was given

\section{Spatial multiple criteria evaluation}

(Figure $10 \& 11$ )

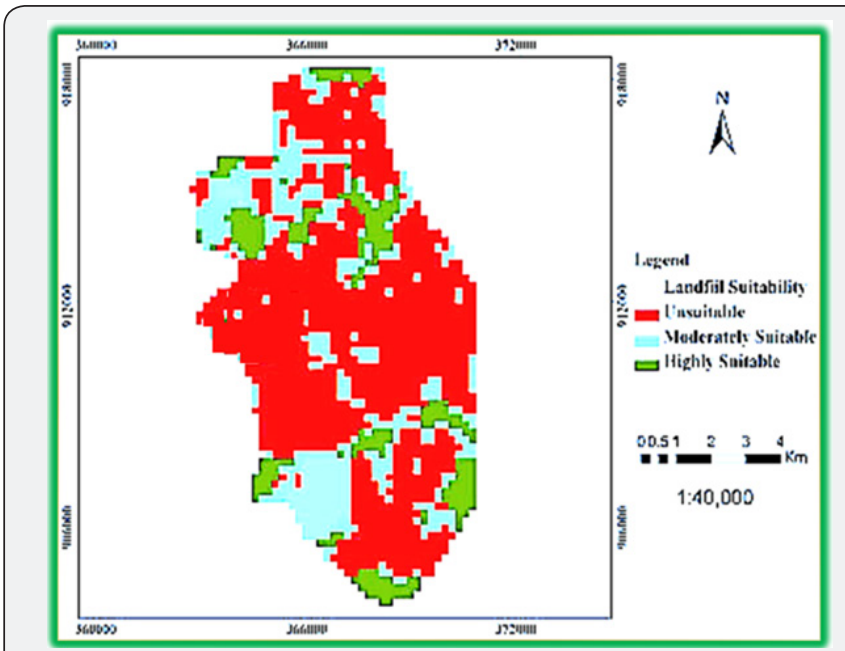

Figure 10: Landfill suitable area evaluation output.

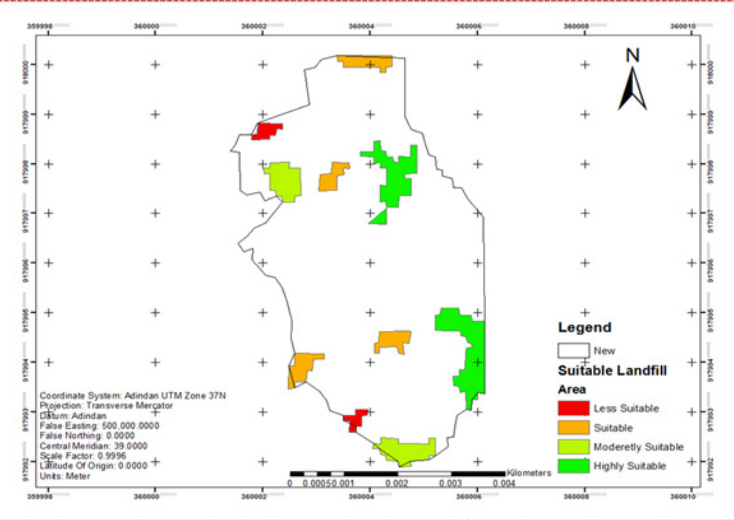

Figure 11: Candidate Landfill Sites Listed in their order of suitability.

\section{Conclusion and Recommendations}

This research used spatial multi-criteria evaluation approach based on Geographic Information System (GIS) analysis, map and priority in order to locate best sites for solid waste disposal in wokite town Ethiopia. GIS and application of multi-criteria analysis can produce suitable sites for solid wastes disposal which is a vital component in solid wastes management. Importantly, the results from this study identified three potential sites suitable for solid wastes disposal, and could be useful for the municipality looking for appropriate sites for the disposal of solid wastes generated within the wolkite, thus the municipality should use the suggested site for solid waste landfill site and change the former one.

\section{References}

1. Chang NB, Parvathinathan G, Breeden BJ (2007) Combining GIS with fuzzy multi criteria decision-making for landfill sitting in a fastgrowing urban region. J Environ Manage 87(1):139-153.

2. WHO (1996) Guides for Municipal Solid Waste Managements in pacific countries. Health Cites, Health Islands Document Series No.6. World Health organization, Western Pacific region, p. 182. 
3. Mcfaden (2003) Environmental hot spots report: identified and evaluated in Palestine. Italian Agency Palestine.

4. Zain T (2009) Some aspects of solid waste disposal site selection, the case of Wadi Madoneh, Jordan. International Journal of Environmental Studies 66(2): 207-219.

5. Akbari V (2011) Landfill Site Selection by combining GIS and fuzzy Multi Criteria Decision Analysis a case study Bandar Abbas, Journal of Department of Surveying and Geomatics Engineering, University of Tehran, Iran.

6. Hasan RM, Tetsuo K, Islam AS (2009) Landfill demand and allocation for municipal solid waste disposal in Dhaka city-an assessment in a GIS environment. Journal of Civil Engineering 37(2): 133-149.

7. Ersoy H, Bulut F (2009) Spatial and multi-criteria decision analysisbased methodology for landfill site selection in growing urban regions. Waste Manag Res 27(5): 489-500.

8. Yahaya S (2010) Land Fill Site Selection for Municipal Solid Waste Management using Geographic Information System and Multi criteria Evaluation. American Journal of Scientific Research.

9. Wind Y, Saaty TL (1980) Marketing applications of the analytic hierarchy process. Management science 26(7): 641-658.

10. Gizachew Kabite (2011) GIS and Remote Sensing based solid waste landfill site selection: a case of Addis Ababa City, Ethiopia. Unpublished master thesis at Addis Ababa University, Ethiopia.
11. Jamjan J (2009) Selection of a potential solid waste landfill site in Nakhon Pathom province by using Geographic Information System (GIS). MSc Thesis, Mahidol University, Thialand.

12. EPA (1995) Decision Maker's Guide to Solid Waste Management, Volume II.

13. UNEP (2005) Selection, Design and Implementation of Economic Instruments in the Solid Waste Management Sector in Kenya: The Case of Plastic Bags. USA, New York.

14. Fesseha Semaw (2011) GIS based solid waste disposal site selection: a case of Woldia Town, Ethiopia. Unpublished master thesis at Addis Ababa University, Ethiopia.

15. EPA (1996) Environmental Guidelines: Solid Waste Landfill. Environmental Protection Authority, 9-61 Goulburn Street, Sydney, pp. 1-95.

16. Friedman (1998) Integrated Solid Waste Management. Mc Graw-Hill: University of California.

17. Hammer G (2003) Solid waste treatment and disposal: effects on public health and environmental safety. Biotechnology Advances 22: 71-79.

18. Martin D, Williams H (1992) Market-area analysis and accessibility to primary health- care centers. Environment and Planning A 24(7): 1009-1019. 